\title{
POTENTIAL FOR IMPROVEMENTS IN MECHANICAL PROPERTIES OF AISI 9260 STEEL BY QUENCHING AND PARTITIONING HEAT TREATMENT
}

Lauro Correa Romeiro Nestor Cezar Heck' Danilo Assad Ludewigs ${ }^{2}$

\begin{abstract}
In this work the quenching and partitioning (Q\&P) treatment is applied to AISI 9260 steel combining different quenching temperatures $(\mathrm{QT})$, and partitioning times and temperatures in order to evaluate mechanical properties (e.g. ultimate tensile strength, elongatin, toughness, and their combination). AISI 9260 steel, besides having the advantage of a lower cost than most of the low alloy steels, can achieve high retained austenite (RA) fraction levels through the application of the Q\&P treatment thanks to its few alloying elements, mainly silicon. The importance of RA lies in its ability to improve ductility and toughness; in this work, RA is determined via X-ray diffraction analysis (XRD) and the mechanical properties are assessed through conventional tensile test and, fracture toughness test (FT) - FT being seldom reported in several Q\&P studies. The results of the present work suggest that the Q\&P treatment applied to AISI 9260 steel could increase its industrial use by virtue of a good combination of strength, ductility and toughness.
\end{abstract}

Keywords: Quenching and partitioning; Retained austenite; AISI 9260 steel.

\section{POTENCIAL PARA MELHORIAS NAS PROPRIEDADES MECÂNICAS DO AÇO AISI 9260 ATRAVÉS DO TRATAMENTO TÉRMICO DE TÊMPERA E PARTICIONAMENTO}

\section{Resumo}

Neste trabalho, o tratamento de têmpera e particionamento (Q\&P) é aplicado ao aço AISI 9260 combinando diferentes temperaturas de têmpera (QT) e tempos e temperaturas de particionamento para avaliar as propriedades mecânicas (resistência à tração, alongamento, tenacidade e sua combinação). O aço AISI 9260, além de ter a vantagem de um custo menor do que a maioria dos aços de baixa liga, pode alcançar altos níveis de fração de austenita retida (AR) através da aplicação do tratamento Q\&P graças aos seus poucos elementos de liga, principalmente silício. A importância da AR consiste na sua capacidade de melhorar a ductilidade e a tenacidade; neste trabalho, a AR é determinada por análise de difração de raios-X (DRX) e as propriedades mecânicas são avaliadas através de ensaio de tração convencional, e do teste de tenacidade à fratura (FT) - FT é raramente relatado em vários estudos com tratamento Q\&P. Os resultados do presente trabalho sugerem que o tratamento Q\&P aplicado ao aço AISI 9260 pode ampliar seu uso industrial em virtude de uma boa combinação de resistência, ductilidade e tenacidade.

Palavras-chave: Têmpera e particionamento; Austenita retida; Aço AISI 9260.

\section{INTRODUCTION}

Quenching and partitioning (Q\&P) heat treatment is receiving a growing attention as a potentially interesting route to promote improvements in the properties of the so-called third generation advanced high strength steel (AHSS) [1,2].
The proposed heat treatment aims at stabilizing the retained austenite (RA) through carbon enrichment of austenite and simultaneous decarburization of the martensitic matrix [3]-carbide formation should be avoided as it may act as a carbon sink.

'Programa de Pós-graduação em Engenharia de Minas, Metalúrgica e de Materiais - PPGE3M, Universidade Federal do Rio Grande do Sul - UFRGS, Porto Alegre, RS, Brasil.E-mail: lauro.romeiro@gmail.com

${ }^{2}$ Durferrit do Brasil Química Ltda., Diadema, SP, Brasil.

2176-I523 (C) 2020 Associação Brasileira de Metalurgia, Materiais e Mineração. Published by ABM. This is an open access paper, published under the Creative Commons CC BY-NC-ND license (Attribution-NonCommercial-NoDerivs) - https://creativecommons.org/licenses/ by-nc-nd/4.0/. 
TRIP steels have been the most tested materials in Q\&P treatment due to their high silicon and/or aluminum content (these elements being used to prevent carbide formation [4]); their use in automotive bodies is highly appreciated for the reason they show good combination of mechanical properties. AISI grade 92XX (mainly AISI 9260 and AISI 9255) has been the second most used in this type of treatment for the sake of being the only steel grade listed where silicon content is high enough to be considered as an alloying element. In this class, steel AISI 9260 is one of the most well-known; it is mainly used in heavy-duty springs (notably in those which are hot wound) in addition to other areas such as the automotive and railway [5]. This steel is nearly identical in composition to S4, a shock-resisting tool steel used for tooling and non-tooling applications - such as coining dies - where impact resistance is important [6]. Besides silicon, the steel also shows a slightly larger amount of manganese than ordinary steels; as known, this element enhances hardenability and reduces the $M_{\mathrm{s}}$ Temperature - a fact that helps a little in increasing the retained austenite fraction at room temperature [7]. These two relatively simple alloying elements allow steel 9260 to show interesting mechanical properties at low cost in comparison to other traditional low alloy steels. Moreover, as it will be presented later in the present work, together with Q\&P treatment they can turn this steel into a good alternative for other industrial applications, where high strength, ductility and toughness is required.

Q\&P process consists of heating the steel either at a temperature of complete austenitization or at an intercritical temperature (aiming at a defined amount of ferrite and austenite), followed by cooling to a temperature between the martensite start $\left(M_{s}\right)$ and finish $\left(M_{f}\right)$, with a subsequent partitioning treatment to enrich the austenite with carbon from martensite, in order to stabilize it when cooled to room temperature [2]. The fractions of austenite and martensite can be controlled according to the selected quenching temperature. The partitioning step can be undertaken at the same quenching temperature (one-step process) or at higher temperature than QT (two-step process) [8]. These Q\&P treatment parameters can be easily applied in existing industrial salt baths heat treatment plants.

In plain carbon steels and the most low-alloy steels, the carbon partitioning between martensite and austenite generally does not take place due to the following reasons: the quenching temperature is too low so that carbon diffusion is impaired [9], or, during tempering carbides precipitation will occur by the reason of the absence of carbide suppressive elements such as silicon and aluminum [10].

The present work focuses on three main heat treatment variables of $\mathrm{Q} \& \mathrm{P}$ treatment: quenching temperature $(\mathrm{QT})$; partitioning temperature $(\mathrm{PT})$ and partitioning time $(\mathrm{Pt})$ in order to search for the best combination of strength, ductility and toughness and their relationship with RA volume fractions. The combination of strength and ductility is evaluated through the known product of strength and elongation (PSE) and toughness through fracture toughness $\mathrm{K}_{\mathrm{IC}}$. Although toughness is an important property sought through Q\&P treatments and frequently mentioned in research articles, fracture toughness, $\mathrm{K}_{\mathrm{IC}}$, is particularly scarcely reported.

\section{EXPERIMENTAL PROCEDURE}

The as-received material, prepared for spring beams manufacturing, was hot rolled in the form of sheets with a nominal thickness of $6 \mathrm{~mm}$; chemical composition is given in Table I.

Before heat treatment, in order to completely remove the decarburized superficial zone, specimens were milling machined on both faces of the sheet until $5 \mathrm{~mm}$ thickness has been achieved. The specimen's dimensions are presented in Figure I for both tensile and fracture toughness tests; specimen's roughness was lower than $0.20 \mathrm{Ra}$.

The specimens used for tensile tests were evaluated after heat treatments without any dimensional modification. For fracture toughness specimens, the notch and tear were made after heat treatment, with final dimensions according to Figure Ic.

For two-step Q\&P heat treatment, the specimens were first heated to $860^{\circ} \mathrm{C}$ and held 12 minutes at that temperature for full austenitization. Thereafter the material was quenched in salt bath to either $183^{\circ} \mathrm{C}$ or $150^{\circ} \mathrm{C}$ and held in the bath for 5 minutes followed by the partitioning step that was carried out at 280 or $400{ }^{\circ} \mathrm{C}$ (PT) in a molten salt bath (Durferrit AS I40) for both 60 or 1200 seconds, and finally water quenched to room temperature. Figure 2 presents the heat treatment scheme and Table 2 summarizes the design of the Q\&P experimental cycles.

The temperature of $280^{\circ} \mathrm{C}$ was chosen because it lies in the range suitable for partitioning temperature and, in addition, it is a typical temperature for austempering steel springs with similar characteristics to material AISI 9260. Likewise, the temperature of $400{ }^{\circ} \mathrm{C}$ was chosen because of its position in the appropriate partitioning temperature range, being also a typical temperature for tempering steel springs with similar material.

The degree of undercooling below $M_{s}$ (martensite start temperature), according to the Koistinen-Marburger relationship [I I], Equation I, was used as base to define the quenching temperature $(\mathrm{QT})$.

$$
f_{m}=1-\exp \left[-0.011 x\left(M_{s}-Q T\right)\right]
$$

Table I. Chemical composition of steel AISI 9260

\begin{tabular}{cccccccccc}
\hline Element & $\mathbf{C}$ & $\mathbf{S i}$ & $\mathbf{M n}$ & $\mathbf{P}$ & $\mathbf{S}$ & $\mathbf{A l}$ & $\mathbf{C r}$ & $\mathbf{M o}$ & $\mathbf{N i}$ \\
\hline Mass fraction wt.\% & 0.60 & $\mathrm{I} .86$ & 0.81 & 0.013 & 0.014 & $0.01 \mathrm{I}$ & 0.12 & 0.03 & 0.08 \\
\hline
\end{tabular}


(a)

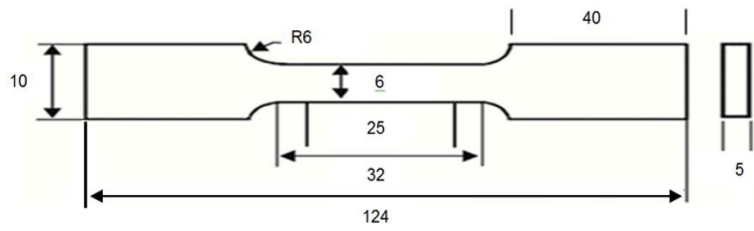

(b)

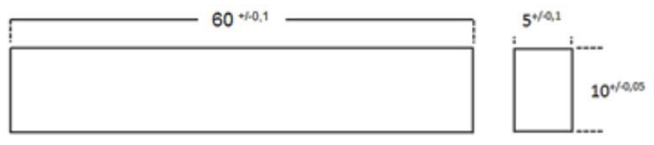

(c)
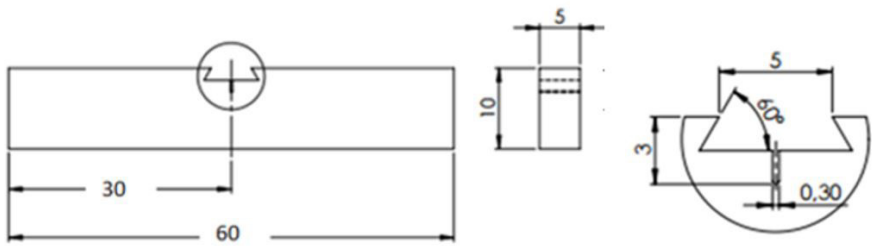

Figure I. Schematic representation of (a) tensile test specimen according to the ASTM E8/E8M-I6a[I2] Standard; (b) fracture toughness specimen before heat treatment; (c) fracture toughness specimen with notch and tear made after heat treatment according to ASTM E-I820-I6.

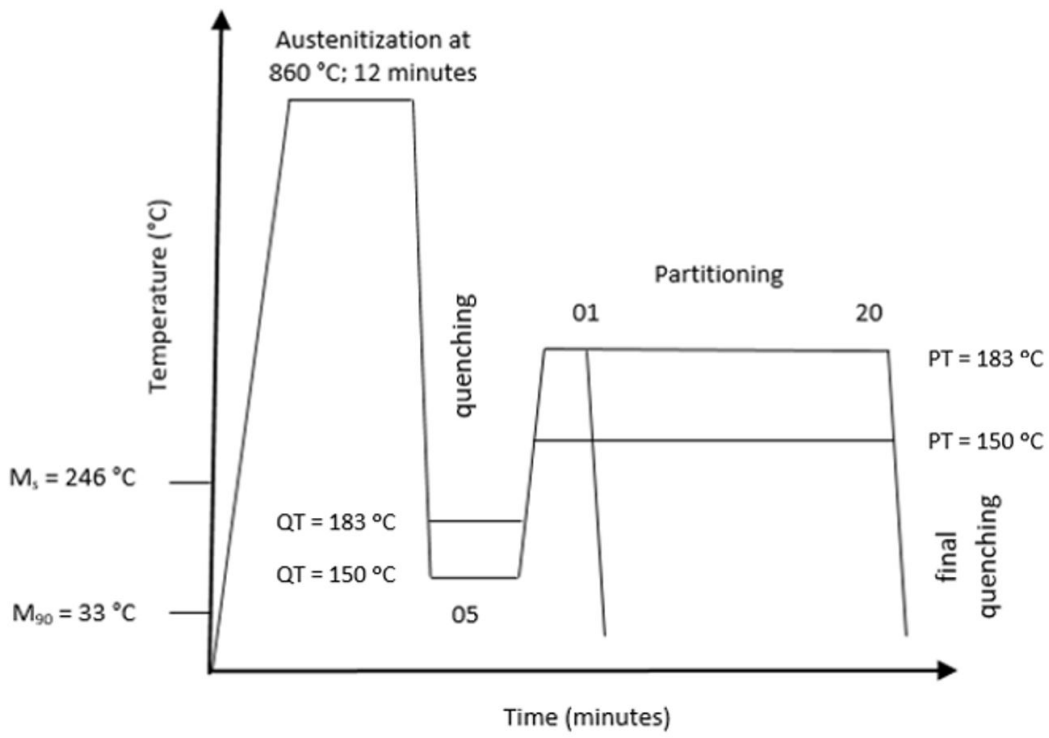

Figure 2. Schematic diagram of two-step Q\&P heat treatment cycles. PT (partitioning temperature); QT (quenching temperature).

Table 2. Q\&P experiments: process design and experiment identification

\begin{tabular}{|c|c|c|c|c|}
\hline \multirow{2}{*}{$\begin{array}{c}\text { Austenitizing } \\
\text { (temperature, time) }\end{array}$} & \multirow{2}{*}{$\begin{array}{c}\text { Quenching } \\
\text { (temperature, time, } \\
\text { medium) }\end{array}$} & \multicolumn{2}{|c|}{ Partitioning } & \multirow{2}{*}{$\begin{array}{l}\text { Experiment } \\
\text { identification }\end{array}$} \\
\hline & & Temperature, medium & Time (s) & \\
\hline \multirow[b]{4}{*}{$860^{\circ} \mathrm{C}$} & \multirow{2}{*}{$150^{\circ} \mathrm{C}$} & $280^{\circ} \mathrm{C}$ & 60 & QPA \\
\hline & & Salt bath & 1200 & QPB \\
\hline & 5 minutes & $400^{\circ} \mathrm{C}$ & 60 & QPC \\
\hline & Salt bath & Salt bath & 1200 & QPD \\
\hline \multirow[t]{4}{*}{12 minutes } & \multirow{2}{*}{$183^{\circ} \mathrm{C}$} & $280^{\circ} \mathrm{C}$ & 60 & QPE \\
\hline & & Salt bath & 1200 & QPF \\
\hline & \multirow{2}{*}{$\begin{array}{l}5 \text { minutes } \\
\text { Salt bath }\end{array}$} & $400^{\circ} \mathrm{C}$ & 60 & QPG \\
\hline & & Salt bath & 1200 & QPH \\
\hline
\end{tabular}


In this equation, $f_{m}$ is the volume fraction of austenite that transforms to martensite when quenching the steel to the temperature QT below $M_{s}$. For the present work, two martensite fractions were designed: $50 \%$ and $65 \%$; this means that, according to Equation I, in order to obtain volume fractions of $50 \%$ and $35 \%$ austenite fraction, QT value must be set to $183^{\circ} \mathrm{C}$ and $150^{\circ} \mathrm{C}$, respectively. The $M_{s}$ temperature $\left(246^{\circ} \mathrm{C}\right)$ was determined using the equation proposed by Imai et al. (apud Fonstein [13]), Equation 2.

$$
M_{s}\left({ }^{\circ} \mathrm{C}\right)=539-423 \% \mathrm{C}-30.4 \% \mathrm{Mn}-7.5 \% \mathrm{Si}+30 \% \mathrm{Al}
$$

All heat treatments were carried out at HEF Durferrit Brazil laboratory. The austenitizing step was undertaken in a furnace under argon protection to avoid decarburization. Salt bath furnaces with 35 Liters capacity and $31.4 \mathrm{~kW}$ power were used for quenching (QT) and partitioning (PT). Both furnaces have sufficient thermal inertia to absorb small thermal charge variations; considering the small weigth of the specimens (less than 360 grams in each experiment), the thermal variation is considered to be diminute (a maximum temperature deviation of $\mathrm{I}^{\circ} \mathrm{C}$ was observed).

The hardness was measured using Rockwell $\mathrm{C}$ method on the surface of all specimens prepared for mechanical testings (tensile and fracture toughness).

Uniaxial tensile testing was conducted on an Instron $5585 \mathrm{H}$ universal testing machine according to the ASTM E8/E8M-I6a [12] using a $25 \mathrm{~mm}$ extensometer. Valid results (breakages within the specified extensometer gage length) of at least three samples from each experiment were used in the analyses. Properties measured via tensile testing were: ultimate tensile strength (UTS), yield strength (YS) - based on the $0.2 \%$ offset method -, elongation $(\varepsilon)$ - determined with the extensometer at fracture -, and the product of ultimate tensile strength and elongation (PSE) - that is an established feature used to evaluate the combination of strength and ductility. The hardness results reported here are the average of three trials.

The austenite fraction was measured using X-ray diffraction (XRD) method; samples were previously mechanically polished until grit number 1200 before each analysis. XRD was carried out on a GE-Seifert Charon XRD M Research edition with Rayflex Analyze software (version 2.503, module Austenite/Nitrate), using a $\mathrm{Cr} \mathrm{K}_{\alpha}$ radiation, operating at
$30 \mathrm{kV}$ and $50 \mathrm{~mA}$. The quantification of austenite content employed three austenite peaks: $\{1 \mathrm{II}\},\{200\},\{220\}$ and three ferrite/martensite peaks: $\{110\},\{200\}$ and $\{211\}$ and integrated intensity comparison. A 2-theta scan was run from 35 to 166 degrees at a step size of 0.01 degree.

The microstructure of the samples was analyzed on a Leica DM2700M optical microscope after conventional Nital etching.

Plain strain fracture toughness was determined using a 3-point single edge notch bend in accordance with ASTM E I820-16 [14]. Fatigue pre-cracking was carried out at a frequency of $3 \mathrm{~Hz}$ and load ratio of 0.1 . Once a fatigue crack length of $1.5 \mathrm{~mm}$ was reached, the specimens were monotonically loaded until fracture on a MTS 810 servo-hydraulic testing machine. Each candidate fracture toughness $\left(\mathrm{K}_{\mathrm{Q}}\right)$ value was calculated from load $(P)$ versus displacement $(v)$ curve. After checking all the validity criteria according to ASTM E 1820, $\mathrm{K}_{\mathrm{Q}}$ was declared valid $\mathrm{K}_{\mathrm{IC}}$.

Optical microscopy was performed to verify the consistency among microstructure, heat treatment and mechanical properties.

\section{RESULTS}

The results of the following tests: surface hardness in Rockwell C (HRC), ultimate tensile strength (UTS), yield stength (YS), elongation $(\varepsilon)$, product of tensile strength and elongation (PSE), Fracture toughness (FT) and retained austenite (RA) are summarized in Table 3.

Tensile testing results were obtained from the average of three valid tests; surface hardness results are average values from specimens used for tensile strength and fracture toughness (results dispersion for all tests was small). The RA volume fraction stems from one of the representative tensile test experiments. FT values result from an average of three valid tests.

The microstructures are presented in Figure 3; All Q\&P microstructures show martensite/bainite; the presence of retained austenite is visible in samples QPC, QPF, QPG and QPH. RA could not be clearly identified by optical metallography for other Q\&P treatments. Nevertheless, the microstructures confirmed the coherence between heat treatments and mechanical properties.

Table 3. Results from hardness and tensile tests.

\begin{tabular}{|c|c|c|c|c|c|c|c|}
\hline $\begin{array}{l}\text { Experiment } \\
\text { Identification }\end{array}$ & $\begin{array}{c}\text { Surface } \\
\text { hardness } \\
\text { (HRC) }\end{array}$ & $\begin{array}{l}\text { UTS } \\
\text { (MPa) }\end{array}$ & $\begin{array}{c}\text { YS } \\
(\mathrm{MPa})\end{array}$ & $\begin{array}{c}\varepsilon \\
(\%)\end{array}$ & $\begin{array}{c}\text { PSE } \\
\text { (MPa.\%) }\end{array}$ & $\begin{array}{c}\text { FT K } K_{\mathrm{lc}} \\
\left(\mathrm{MPa} \cdot \mathrm{m}^{1 / 2}\right)\end{array}$ & $\begin{array}{l}\text { RA } \\
(\%)\end{array}$ \\
\hline QPA & 57.5 & 2409 & 1202 & 7.0 & 16860 & 26.9 & 13.2 \\
\hline QPB & 55,2 & 2143 & 1637 & 15.0 & 32064 & 34.4 & 11.8 \\
\hline QPC & 53,2 & 1923 & 1697 & 17.5 & 33709 & 42.0 & 18.6 \\
\hline QPD & 52,0 & 1875 & 1707 & 16.2 & 30347 & 49.9 & 13.8 \\
\hline QPE & 57.3 & 2347 & 1187 & 11.8 & 27790 & 24.3 & 15.3 \\
\hline QPF & 54.1 & 1972 & 1489 & 15.6 & 30684 & 38.3 & 16.3 \\
\hline QPG & 50.5 & $180 \mid$ & 1560 & 23.7 & 42617 & 50.4 & 21.5 \\
\hline QPH & 48.9 & 1645 & $|46|$ & 20.6 & 33913 & 59.0 & 17.3 \\
\hline
\end{tabular}




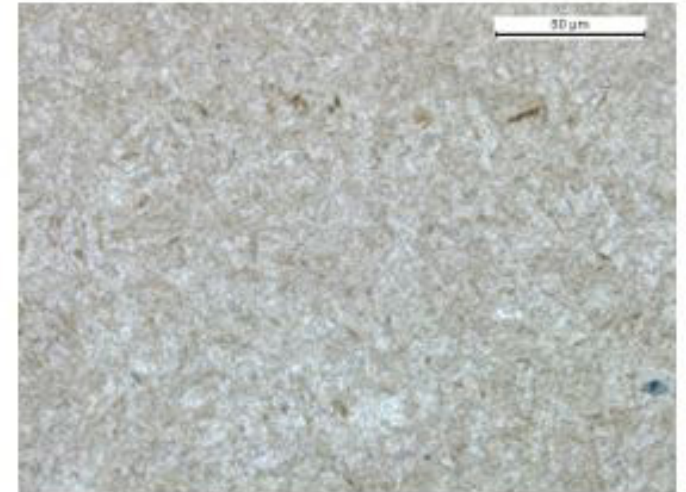

QPA

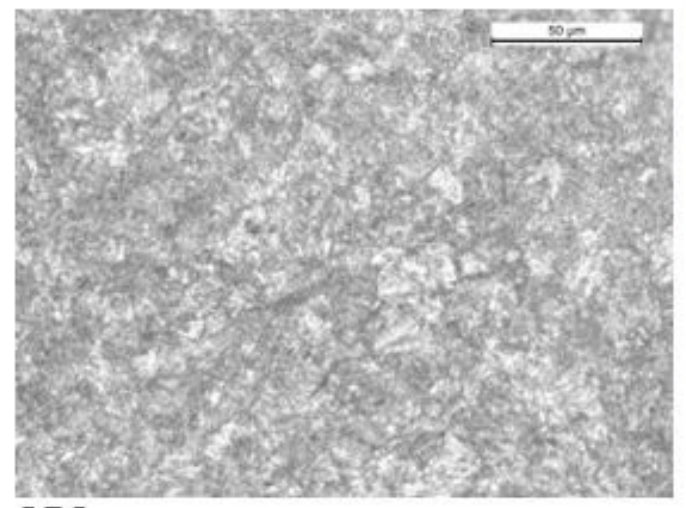

QPC

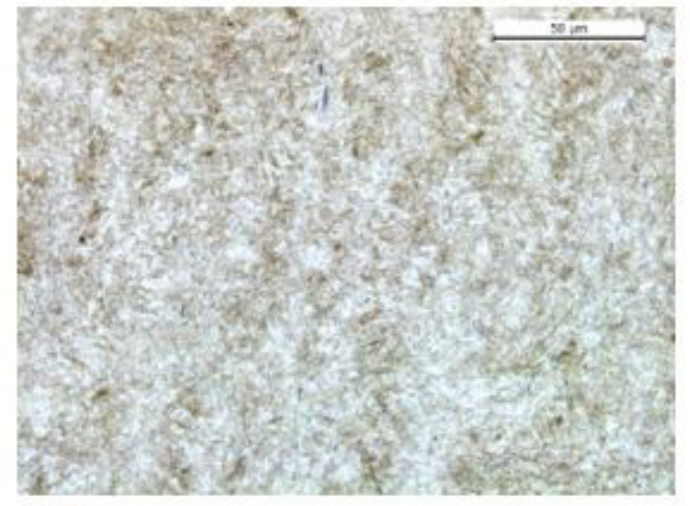

QPE

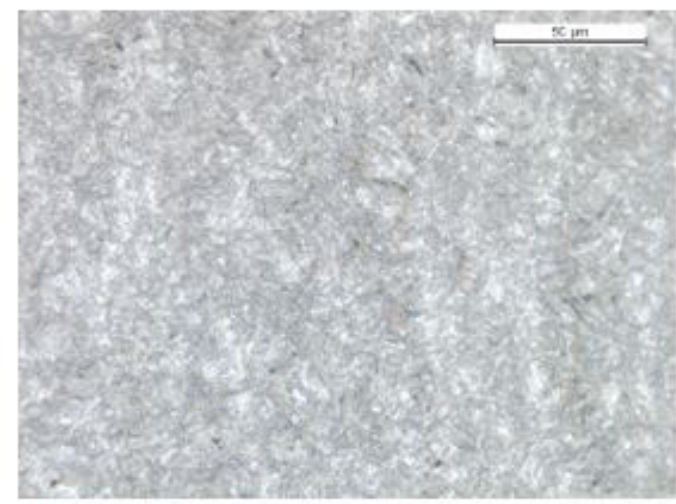

QPG

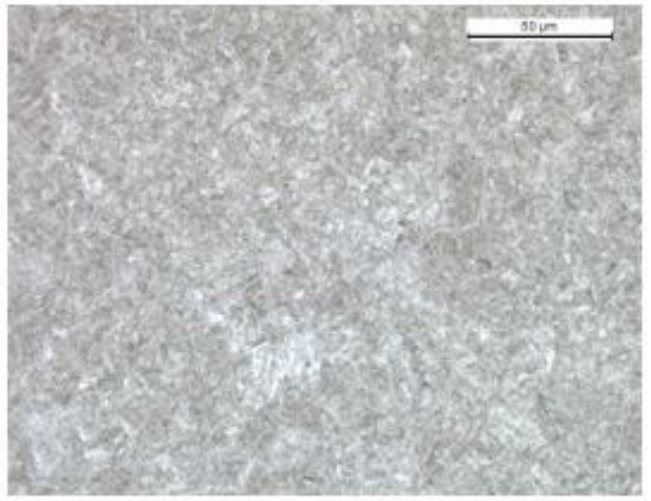

QPB
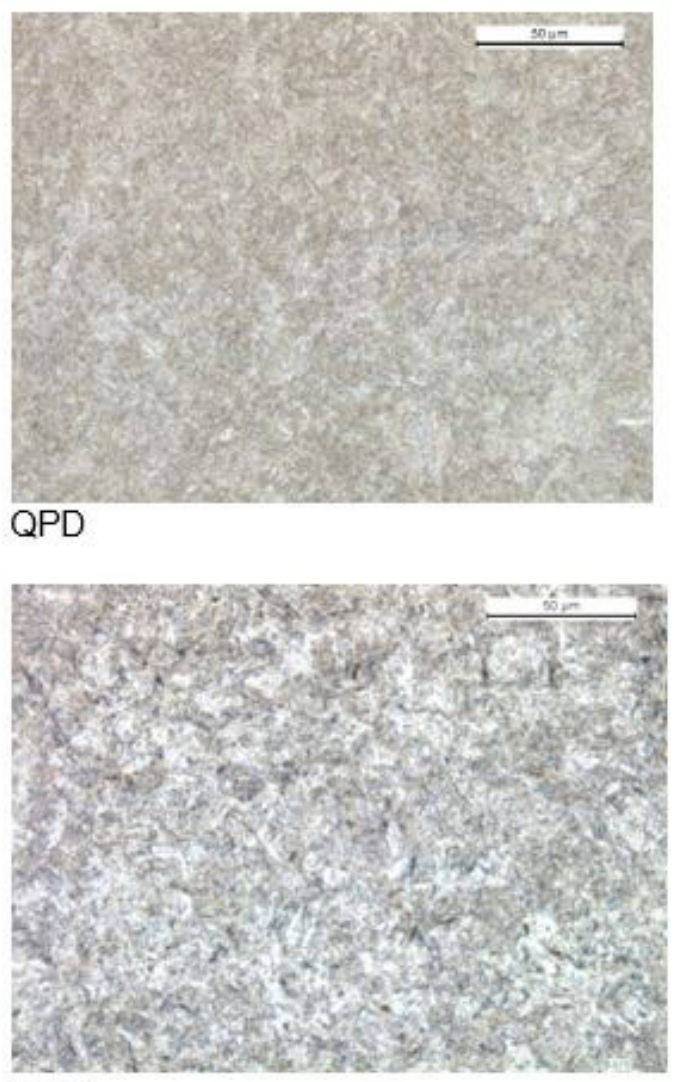

QPF

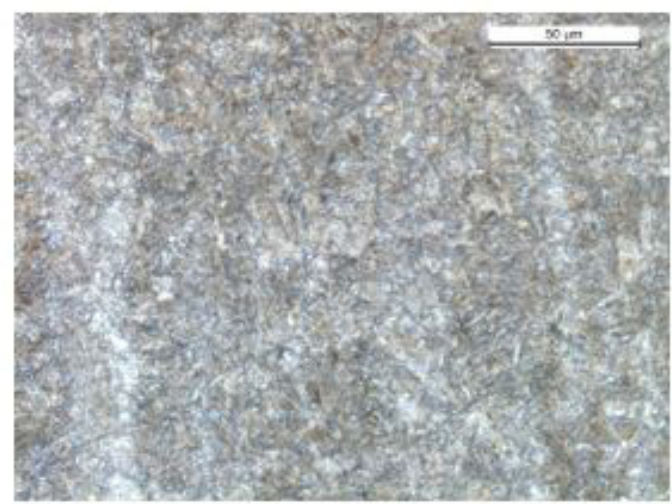

$\mathrm{QPH}$

Figure 3. Microstructures of quenching and partitioning experiments: QPA; QPB; QPC; QPD; QPE; QPF; QPG; QPH; Nital etching. 


\section{COMMENTS AND DISCUSSION}

The main focus of the work is to evaluate the combination of strength and ductility (PSE) and toughness as already cited. PSE is shown in Figure 4; as can be seen, Q\&P experiments results range from 16,860 to 42,617 . Almost all Q\&Ps treatments presented PSE higher than

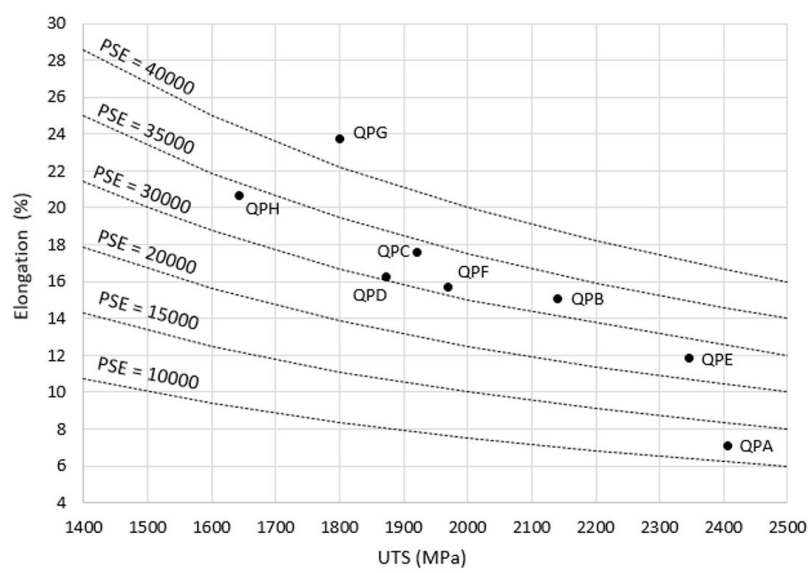

Figure 4. Product of strength and elongation (PSE).

(a)

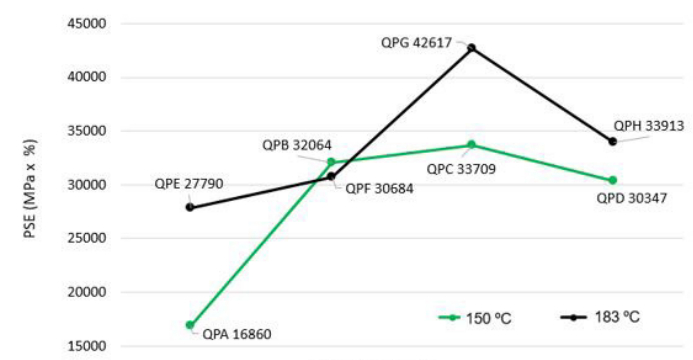

(b)

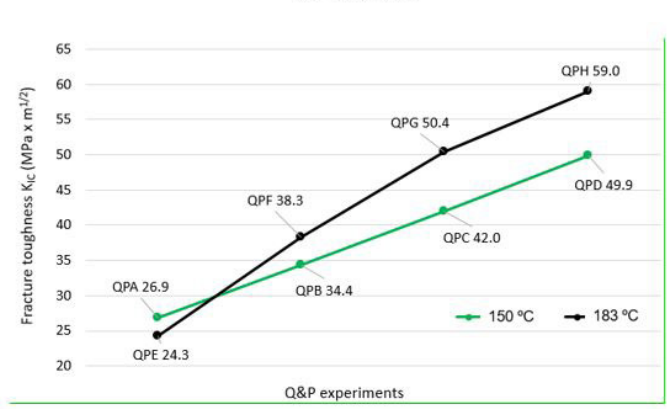

(c)

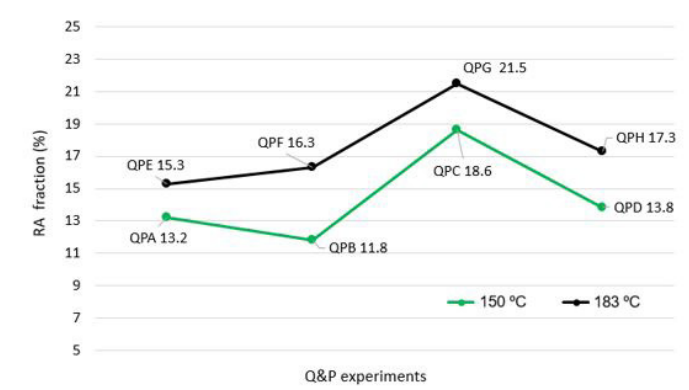

Figure 5. Effects of quenching temperature on: PSE (a), Fracture toughness $\mathrm{K}_{\mathrm{IC}}(\mathrm{b})$ and $\mathrm{RA}(\mathrm{c})$.
30,000 . Values above 30,000 could be considered very good since low alloy steels, which might present similar applications to AISI 9260 steel, such as AISI 4340, AISI 5 I60, AISI 8660 and AISI 9260 itself, have PSE values significantly lower than 30,000 when quenched and tempered in any of the temperature conditions between 205 and $425{ }^{\circ} \mathrm{C}$ (according to the database of CES EduPack software from Granta Design - UK company specializing in information technology materials). QPG treatment presented the highest PSE (> $40000 \mathrm{MPa} . \%)$, the highest RA fraction (21.5\%) and the second highest FT (50.4 MPa.m $\left.{ }^{1 / 2}\right)$ indicating the positive effect of RA fraction on the combination of strength, ductility and toughness. QPH also deserves prominence for nearby results.

\section{I Effects of Quenching Temperature (QT) on Mechanical Properties}

Figure 5 presents the QT effects on the product of strength and elongation (PSE), fracture toughness $\mathrm{K}_{\mathrm{IC}}(\mathrm{FT})$ and retained austenite (RA); Q\&P treatments are separated into two groups, according to the quenching temperature (QT), and arranged sequentially with the same partitioning times and temperatures (QPA with QPE, QPB with QPF, QPC with QPG, and QPD with QPH) with the purpose of directing the analysis only to the QT effect.

It is clear that PSE and FT showed higher results for $183^{\circ} \mathrm{C}$ quenching temperature with exceptions of minor significance. The following metallurgical factors may explain QT effects:

- Lower fraction of martensite/bainite present at the end of Q\&P treatments with quenching to $183^{\circ} \mathrm{C}$, i.e. greater fraction of retained austenite;

- The martensite originated from quenching to $183^{\circ} \mathrm{C}$ possibly presents lower carbon for RA fraction is higher at the end of treatment (which means less carbon migrating from martensite to austenite during partitioning).

\subsection{Effects of Partitioning Temperature and Time on Mechanical Properties}

The effects of partitioning temperature and time on ultimate tensile strength (UTS), elongation $(\varepsilon)$, product of strength and elongation (PSE), retained austenite (RA) and fracture toughness $\mathrm{K}_{\mathrm{IC}}(\mathrm{FT})$ are presented in Figure 6.

For an increment of 60 to 1200 seconds, an increase in PSE for PT equal to $280^{\circ} \mathrm{C}$ and a decrease for PT equal to $400^{\circ} \mathrm{C}$ was noticed.

With reference to PT equal to $280^{\circ} \mathrm{C}$, the slight reduction in UTS is countered by the more pronounced increase in elongation, resulting in a PSE increase. This increasing in PSE is directly related to a higher tempering 
(a)

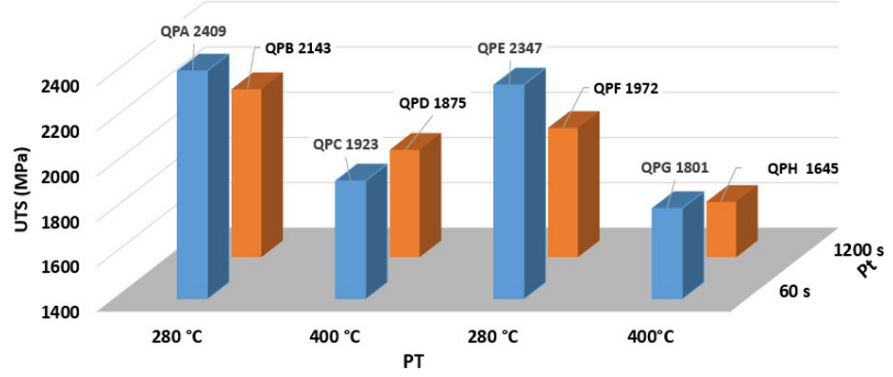

(b)

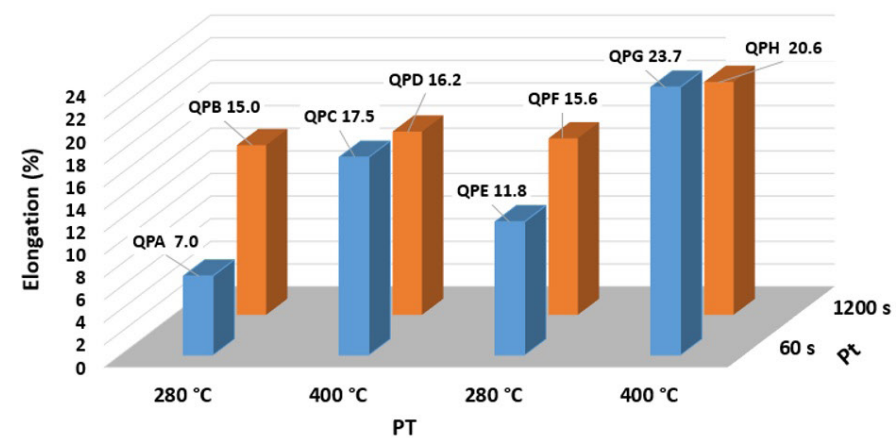

(c)

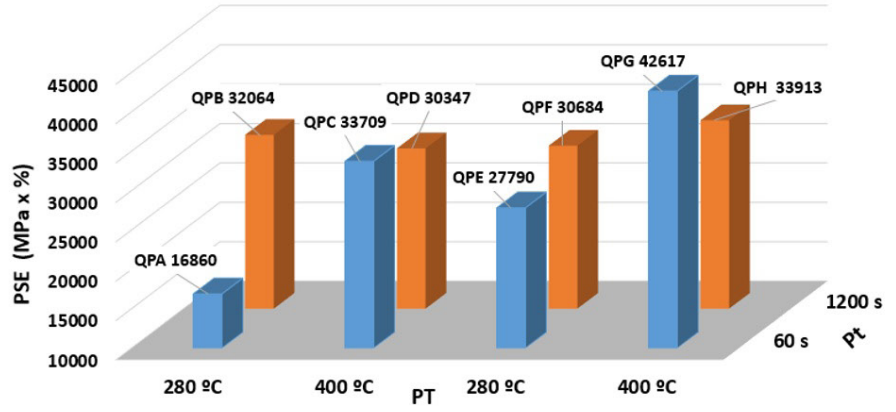

(d)

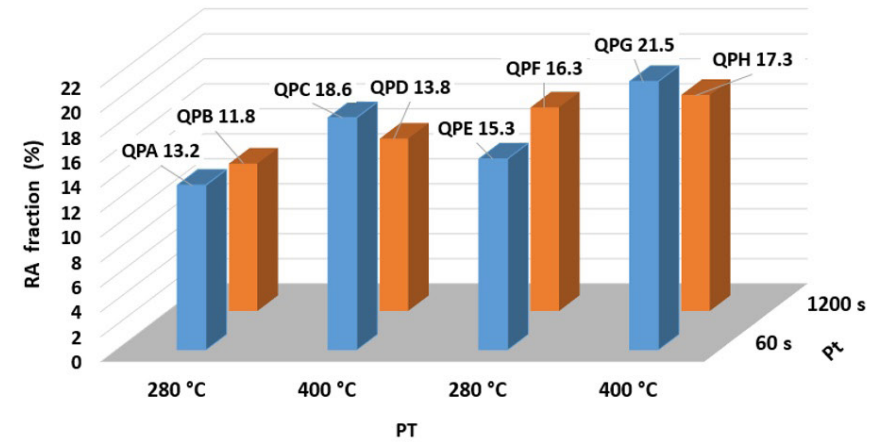

(e)

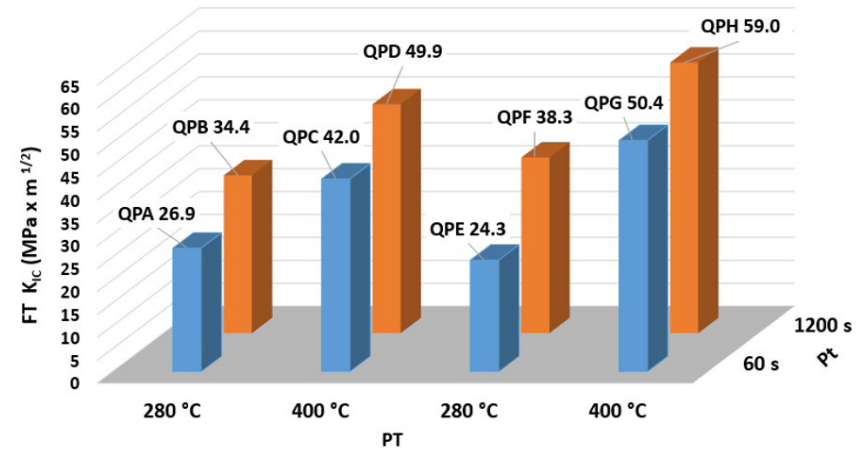

Figure 6. Effects of partitioning temperature and time on: UTS (a), elongation (b), PSE (c), RA (d), fracture toughness $\mathrm{K}_{\mathrm{IC}}$ (e); PT (partitioning temperature) and $\mathrm{Pt}$ (partitioning time). 
intensity by reason of a longer partitioning time since the influence of RA is small as can be seen in Figure 6d.

With respect to PT equal to $400^{\circ} \mathrm{C}$, the reduction (although small) in both strength and elongation, resulted in a reduction in PSE, which is in line with the studies of Acharya and Bhat [15]. The strength reduction points to the tempering intensity as the main cause. At same time, the reduction in elongation leads to think of a link with the reduction in the retained austenite fraction.

With the increase in partitioning time, there was also an increase in fracture toughness, following the opposite behavior to that of UTS suggesting that main influence is tempering during the partitioning step.

For an increase in PT from 280 to $400^{\circ} \mathrm{C}$ there was an overall increase in PSE, except for Pt of I $200 \mathrm{~s}$ with QT of $150^{\circ} \mathrm{C}$.

With the PT increasing from 280 to $400{ }^{\circ} \mathrm{C}$, there was a reduction in UTS and an increase in the elongation that are both explained by the greater tempering intensity and RA fraction increasing. These same reasons explain the FT increasing.

The trend in UTS reduction with increasing partitioning time and temperature is in agreement with other Q\&P studies $[16,17]$.

\subsection{Retained Austenite}

It is clear, according to the Figure $5 c$, that treatments with quenching to the temperature of $183^{\circ} \mathrm{C}$ reached higher RA fractions than the treatments with quenching to $150^{\circ} \mathrm{C}$, indicating that $50 \%$ austenite $\left(183^{\circ} \mathrm{C}\right)$ allowed for a greater fraction of this phase to be remaining at the end of the treatment (if compared to $35 \%$ RA for $150^{\circ} \mathrm{C}$ ). The following austenite fractions changes occurred during partitioning and cooling to room temperature:

- For quenching to the temperature of $183^{\circ} \mathrm{C}$, a range of 15.3 to 21.5 vol.\% RA was achieved at room temperature (meaning 31 to $43 \%$ of the designed austenite value at this QT), i.e. between 57 and $69 \%$ of the designed austenite value at this QT was transformed into martensite/bainite, in consonance with the partitioning phenomenon; while,

- For quenching to the temperature of $150^{\circ} \mathrm{C}$, a range of II.8 to $18.6 \%$ RA was achieved at room temperature (meaning 34 to $53 \%$ of the designed austenite value at this QT), i.e. between 47 to $66 \%$ of the designed austenite value at this QT was transformed into martensite/bainite, again in consonance with the partitioning phenomenon.

As stated above, the austenite after quenching to QT remains only partially. The fact this austenite does not receive a sufficient carbon (from martensite, to the point of stabilizing it completely during partitioning) might be explained by: (a) precipitation of cementite, bainite formation, and entrapment of carbon atoms at dislocations during the partitioning stage [16- |8]; and/or (b) higher carbon solubility in tetragonal ferrite than carbon solubility at equilibrium (as per the traditional iron-carbon phase diagram) $[19,20]$.

From the results and considerations mentioned above it is possible to infer that there is an ideal QT (ideal austenite fraction) that allows the highest austenite retention at the end of a Q\&P treatment.

RA fraction increases when PT rises from 280 to $400^{\circ} \mathrm{C}$ while RA fraction decreases for longer partitioning time (Figure 6d); the formation of bainite and precipitation of carbides during partitioning can explain this fact [16,2I]. In brief, higher PT and shorter partitioning time (associated with the QT of $183^{\circ} \mathrm{C}$ ) favor austenite stabilization - as seen with the QPG experiment, which reached the largest RA fraction (21.5\%).

In virtue of the importance attributed to retained austenite as a means of improving mechanical properties combination, an overview is presented in Figure 7. The higher the RA amount (lower martensite fraction) the lower UTS and the greater elongation, PSE and fracture toughness - all of them technically expected. It is observed that the effect of RA on the increase of the elongation is more pronounced than its impact on the strength reduction, so that the combination of these properties, concretized in the PSE, ends up having the same rising behavior as a function of the RA fraction. Moreover, among the mechanical properties, the minor RA influence was on FT.

The quite low value of the coefficient of determination (R-squared) suggests the significant concurrence of other metallurgical factors influencing the results such as: carbon content in fresh martensite, amount of formed bainite during partitioning, intensity of tempering and carbon content in RA, with emphasis in tempering during partitioning step.

Among selected results for RA fraction from other Q\&P studies using AISI 9260 steel the highest value reached $24.9 \%$ according to Wolfram [2I] with QT of $190^{\circ} \mathrm{C}$, PT of $400{ }^{\circ} \mathrm{C}$ PT with $240 \mathrm{~s}$.

\section{CONCLUSIONS}

Results from tensile tests with hot rolled AISI 9260 submitted to several Q\&P cycles indicate that the best combination of strength and elongation (PSE $=42617 \mathrm{MPa} . \%$ ) is achieved by quenching to $183^{\circ} \mathrm{C}$ and partitioning at $400^{\circ} \mathrm{C} / 60 \mathrm{~s}$ (experiment QPG); the high fraction volume of retained austenite $(21.5 \%)$ must be taken into account when referring to this outstanding ductility.

Thanks to a general better combination of strength and ductility plus fracture toughness results (experiments QPG and QPH) it can be concluded that partitioning step conducted at $400{ }^{\circ} \mathrm{C}$ should be favored over partitioning at $280^{\circ} \mathrm{C}$.

A maximum austenite remaining value of $53 \%$ was achieved (with respect to the designed austenite at QT) 

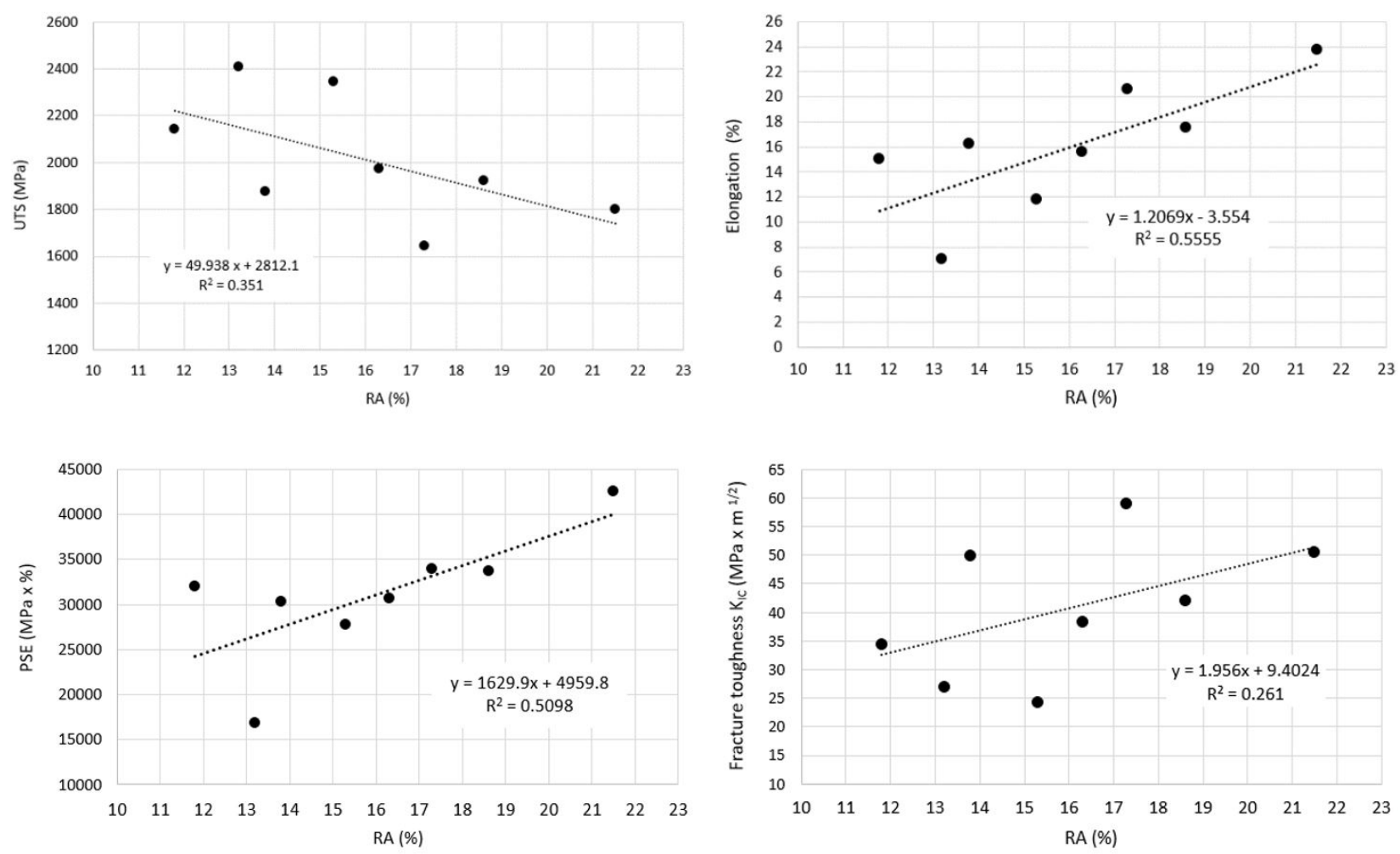

Figure 7. Effects of retained austenite on UTS, elongation, PSE and fracture toughness; Q\&P experiments.

during partitioning, signalizing the concurrence of other metallurgical phenomena besides the migration of carbon from martensite to austenite such as carbide precipitation, which may lead to tempering and bainite formation.

An increasing in quenching temperature (from 150 to $183^{\circ} \mathrm{C}$ ), although it has resulted in a reduction in strength (UTS), provided an increase in both PSE and fracture toughness; the following reasons were pointed out for this behavior: lower martensite fraction, lower possibility of reduction of carbon content in martensite, and higher fraction of austenite retained at the end of treatment.

Furthermore, an increasing in partitioning time (from 60 to 1200 s) promoted: a reduction in UTS (attributed mainly to higher intensity of martensite tempering); an increasing in elongation and PSE at partitioning temperature of $280^{\circ} \mathrm{C}$ (attributed primarily to higher martensite tempering intensity and bainite formation); a reduction in elongation and PSE at partitioning temperature of $400{ }^{\circ} \mathrm{C}$ (attributed mainly to the reduction of retained austenite fraction and carbide precipitation); and, an increasing in fracture toughness (referred mainly to the reduction of strength, martensite tempering and a larger fraction of retained austenite).

Regarding the potential of industrial applications, Q\&P treatment cycles on AISI 9260 steel grade increases its competitiveness in comparison to traditional low alloys steels based on both technical features (mechanical properties) and lower specific costs. It is noteworthy to mention, the Q\&P treatment can be easily applied in existing industrial salt baths heat treatment plants, virtually without additional costs.

\section{Acknowledgements}

The authors gratefully acknowledge the support of the Brazilian subsidiary of HEF Durferrit for the use of its heat treatment laboratory facilities; the Physical Metallurgy Laboratory, LAMEF-UFRGS, for conducting the mechanical tests and X-ray diffraction analyzes; and Laminação São Joaquim for having kindly provided the experimental materials.

\section{REFERENCES}

I Bhattacharya D. Metallurgical perspectives on advanced sheet steels for automotive applications. In: Weng Y, Dong H, Gan Y, editors. Advanced steels. Heidelberg: Springer; 20I I. 5 I I p.

2 De Moor E, Lacroix S, Clarke AJ, Penning J, Speer JG. Effect of retained austenite stabilized via quench and partitioning on the strain hardening of martensitic steels. Metallurgical and Materials Transactions A: Physical Metallurgy and Materials Science. 2008;39A:2586-2595. 
3 Ghazvinloo H, Honarbakhsh-Raouf A. Effect of partitioning time on microstructural evolution of a C-Mn-Si steel in two-step quenching and partitioning process. Journal of Materials and Environmental Science. 20 I4;5(6): I 988- I993.

4 Arlazarov A, Bouaziz O, Masse JP, Kegel F. Characterization and modeling of mechanical behavior of quenching and partitioning steels. Materials Science and Engineering A. 201 5;620:293-300.

5 Putatunda SK. Influence of austempering temperature on microstructure and fracture toughness of a high-carbon, high-silicon and high-manganese cast steel. Materials \& Design. 2003;24(6):435-443.

6 Chandler $\mathrm{H}$, editor. Heat treater's guide: practices and procedures for irons and steels. 2nd ed. Materials Park: ASM International; 1995. 904 p.

7 Rana R, Singh SB. Automotive steels: design, metallurgy, processing and applications. Amsterdam: Elsevier; 20 I6. 478 p. (Woodhead Publishing Series in Metals and Surface Engineering).

8 Han X, Zhong Y, Yang K, Cui Z, Chen J. Application of hot stamping process by integrating quenching \& partitioning heat treatment to improve mechanical properties. Procedia Engineering. 2014;81:1737-I 743.

9 Speer JG, Rizzo FC, Matlock DK, Edmonds DV. The “Quenching and partitioning” process: background and recent progress. Materials Research. 2005;8(4):4I 7-423.

I0 Speer JG, Edmonds DV, Rizzo FC, Matlock DK. Partitioning of carbon from supersaturated platEs of ferrite, with application to steel processing and fundamentals of the bainite trasnformation. Current Opinion in Solid State and Materials Science. 2004;8:219-237.

I I Koistinen DP, Marburguer RE. A general equation prescribing the extent of the austenite-martensite transformation in pure iron-carbon alloys and plain carbon steels. Acta Metallurgica. 1959;7:59-60.

I2 ASTM E8 / E8M- I6a, Standard Test Methods for Tension Testing of Metallic Materials, ASTM International, West Conshohocken, PA, 2016

I 3 Fonstein N. Advanced higt strenght sheet steels: physical metallurgy, design, processing, and properties. New York: Springer; 2015, $396 \mathrm{p}$.

I4 ASTM EI820-16, Standard Test Method for Measurement of Fracture Toughness, ASTM International, West Conshohocken, PA, 2016

I5 Acharya PP, Bhat R. Structure-property correlation of quenching and partitioning heat treated silicon-manganese steel. Silicon. 2018. In press.

I6 Clarke AJ, Speer JG, Matlock DK, Rizzo FC, Edmonds DV, Santofimia MJ. Influence of carbon partitioning kinetics on final austenite fraction during quenching and partitioning. Scripta Materialia. 2009;6I:I49-I52.

17 Clarke A. Carbon partitioning into austenite from martensite in a silicon-containing high strength sheet steel [thesis]. Golden: Colorado School of Mines; 2006 [cited 2019 Apr 23];34:573-580. Available at: http://hdl.handle. net/ I I I 24/ I 70369

I 8 Jang JH, Bhadeshia HKDH, Suh DW. Solubility of carbon in tetragonal ferrite in equilibrium with austenite. Scripta Materialia. 2013;68:195-198.

19 Bhadeshia HKDH. Carbon in cubic and tetragonal ferrite. Philosophical Magazine. 2013;93(28-30):34I7-3429.

20 Edmonds DV, He K, Rizzo FC, De Cooman BC, Matlock DK, Speer JG. Quenching and partitioning martensite: a novel steel heat treatment. Materials Science and Engineering A. 2006;438-440:25-34.

21 Wolfram PC. The microstructural dependence of wear resitance in austenite containing plate steels [thesis]. Golden: Colorado School of Mines; 2013.

Received: 23 Apr 2019

Accepted: 29 Jan 2020 